\title{
Prevalence of tick-borne encephalitis virus in Ixodes ricinus ticks in northern Europe with particular reference to Southern Sweden
}

\author{
John H-O Pettersson ${ }^{1}$, Irina Golovljova² ${ }^{2}$ Sirkka Vene ${ }^{3}$ and Thomas GT Jaenson ${ }^{1 *}$
}

\begin{abstract}
Background: In northern Europe, the tick-borne encephalitis virus (TBEV) of the European subtype is usually transmitted to humans by the common tick Ixodes ricinus. The aims of the present study are (i) to obtain up-to-date information on the TBEV prevalence in host-seeking I. ricinus in southern and central Sweden; (ii) to compile and review all relevant published records on the prevalence of TBEV in ticks in northern Europe; and (iii) to analyse and try to explain how the TBE virus can be maintained in natural foci despite an apparently low TBEV infection prevalence in the vector population.
\end{abstract}

Methods: To estimate the mean minimum infection rate (MIR) of TBEV in I. ricinus in northern Europe (i.e. Denmark, Norway, Sweden and Finland) we reviewed all published TBEV prevalence data for host-seeking I. ricinus collected during 1958-2011. Moreover, we collected 2,074 nymphs and 906 adults of I. ricinus from 29 localities in Sweden during 2008. These ticks were screened for TBEV by RT-PCR.

Results: The MIR for TBEV in nymphal and adult I. ricinus was $0.28 \%$ for northern Europe and $0.23 \%$ for southern Sweden. The infection prevalence of TBEV was significantly lower in nymphs (0.10\%) than in adult ticks (0.55\%). At a well-known TBEV-endemic locality, Torö island south-east of Stockholm, the TBEV prevalence (MIR) was $0.51 \%$ in nymphs and $4.48 \%$ in adults of I. ricinus.

Conclusions: If the ratio of nymphs to adult ticks in the TBEV-analysed sample differs from that in the I. ricinus population in the field, the MIR obtained will not necessarily reflect the TBEV prevalence in the field. The relatively low TBEV prevalence in the potential vector population recorded in most studies may partly be due to: (i) inclusion of uninfected ticks from the 'uninfected areas' surrounding the TBEV endemic foci; (ii) inclusion of an unrepresentative, too large proportion of immature ticks, compared to adult ticks, in the analysed tick pools; and (iii) shortcomings in the laboratory techniques used to detect the virus that may be present in a very low concentration or undetectable state in ticks which have not recently fed.

Keywords: Ixodes ricinus, Minimum infection rate, Real-time PCR, Sweden, Norway, Denmark, Finland, TBE, Tick-borne encephalitis virus, Virus prevalence

\footnotetext{
* Correspondence: Thomas.Jaenson@ebc.uu.se

${ }^{1}$ Medical Entomology Unit, Subdepartment of Systematic Biology,

Department of Organismal Biology, Evolutionary Biology Centre, Uppsala

University, Norbyvägen 18d, SE-752 36, Uppsala, Sweden

Full list of author information is available at the end of the article
} 


\section{Background}

The common tick Ixodes ricinus is the most important arthropod vector of pathogens of human diseases in Europe $[1,2]$. One of these pathogens potentially causing human disease is the tick-borne encephalitis virus (TBEV), a member of the tick-borne group within the genus Flavivirus [3], family Flaviviridae [4]. Tick-borne encephalitis (TBE) is a potentially fatal disease syndrome of humans and some other mammals [5]. TBE is endemic in central, eastern, and northern Europe eastwards through Russian Siberia and China [6-8]. During the last two decades, 1990-2009, an annual mean incidence of 2,815 cases of human TBE was recorded for Europe, while a corresponding annual mean incidence of 5,682 human TBE cases was reported from Russia [7].

Currently, the TBEV complex is considered to encompass three virus subtypes; the European (TBEV-Eu), the Far-Eastern (TBEV-Fe), and the Siberian TBEV (TBEV$\mathrm{Sib})[4,5,9]$. TBEV-Eu is mainly vectored by I. ricinus while I. persulcatus is the primary vector of the Siberian and Far Eastern subtypes [5]. The European subtype is present in certain foci in Sweden, Norway, Denmark, Finland, Russia, the Baltic countries and southwards through several east, central and south European countries [7]. The Far-Eastern subtype, in contrast to the Siberian subtype, has not yet been found in Northern Europe. However, it is present in populations of $I$. persulcatus in the Baltic area [10] and western Russia not far from the Finnish border. Its geographical range extends eastwards to China and Japan $[9,11]$. The Siberian subtype is found in Siberia, eastern Europe and western Russia [9,10,12], but also in Finland [13]. All three subtypes are known to co-circulate in areas where the geographical ranges of $I$. ricinus and I. persulcatus overlap $[14,15]$. The European subtype is the only subtype so far found in ticks in Sweden [16-18], Norway [19] and Denmark [20]. In Finland, both the European and Siberian viruses have been detected in I. persulcatus. Only the former virus subtype has been recorded from $I$. ricinus in Finland [13,21,22].

More than $70 \%$ of TBEV infections in humans are without symptoms [5]. Virulence and disease symptoms exhibit characteristic differences related to virus subtype. The overt disease caused by TBEV-Eu may range from a relatively mild influenza-like infection to a severe, life-threatening disease with paralytic long-lasting sequelae. The mortality rate caused by infections with TBEV-Eu is about $1-2 \%$ while that of the Siberian subtype rarely exceeds $8 \%$ [5]. The Far-Eastern subtype often causes a monophasic disease with a high rate of severe neurologic sequelae and a mortality rate that sometimes exceeds $20 \%$ [5,6,23-25].

In Sweden the first human TBE case was described in 1954 [26]. Four years later the virus was isolated from $I$. ricinus ticks and from a patient. Since then, the annual incidence of human TBE has increased from 60-80 cases/ year before the 1990 s to more than 100 cases/year since 2000, thereafter increasing even further to more than 150 cases/year since 2006 with a significant increasing trend during 2000-2012 [27]. This rise in TBE incidence in Sweden is attributed to a combination of biotic and climatological factors, particularly high abundance of roe deer and other cervids in southern Sweden since the mid1980 s and a warmer climate with a prolonged vegetation period [27,28]. Based on data for the year 2009 for the Scandinavian countries, Sweden has the highest TBE incidence (2.3 per 100 000), followed by Finland ( 0.5 per 100 000), Norway (0.2 per 100 000), and Denmark (0.02 per 100 000) [7]. The only regional estimates of TBEV prevalence in $I$. ricinus published so far refer to southwestern Sweden. They range from $0.10 \%$ to $0.42 \%$ [29].

Despite the great public health importance of TBE, some aspects of the ecology of TBEV have not been adequately investigated. One characteristic of the ecology of the TBE virus is its irregular distribution over a large geographical range with a patchy occurrence in restricted foci of limited size [30-33]. This is in contrast to several other Ixodes-transmitted pathogens, such as Anaplasma phagocytophilum [34,35] and some genospecies in the Borrelia burgdorferi sensu lato complex, the endemic regions of which are extensive and sometimes even include whole countries [36,37]. Another peculiarity of TBEV, which has puzzled scientists for a long time, is the low prevalence of the virus, usually $<1 \%$, in the $I$. ricinus population. This phenomenon also differs from the usually significantly higher prevalence of most of the bacteria vectored by $I$. ricinus $[34,35,37,38]$. Thus, the question arises how the virus can be maintained in a small focus for many years despite such apparently low infection prevalence in I. ricinus.

Here we present TBEV prevalence data based on virus screening of $I$. ricinus collected at 29 localities in the main TBEV-endemic regions of southern Sweden during 2008. We also provide a summary of all relevant, published TBEV-prevalence data for I. ricinus collected in Sweden and its three neighbouring countries Denmark, Norway and Finland.

\section{Methods}

\section{Tick collection}

Between May-September 2008, host-seeking (that usually do not contain any visible blood in the gut) I. ricinus were collected at 29 localities in southern and central Sweden (Figure 1, Additional file 1: Table S1) as previously described [39]. In short, a total of 2,074 nymphs and 906 adult ticks (481 females and 425 males) were collected by a person pulling a $1 \times 1\left(1 \mathrm{~m}^{2}\right)$ white flannel cloth placed horizontally on the ground vegetation in deciduous or mixed deciduous/coniferous woodland biotopes [40]. At Norbo Finnmark, 12 adult I. ricinus, four 


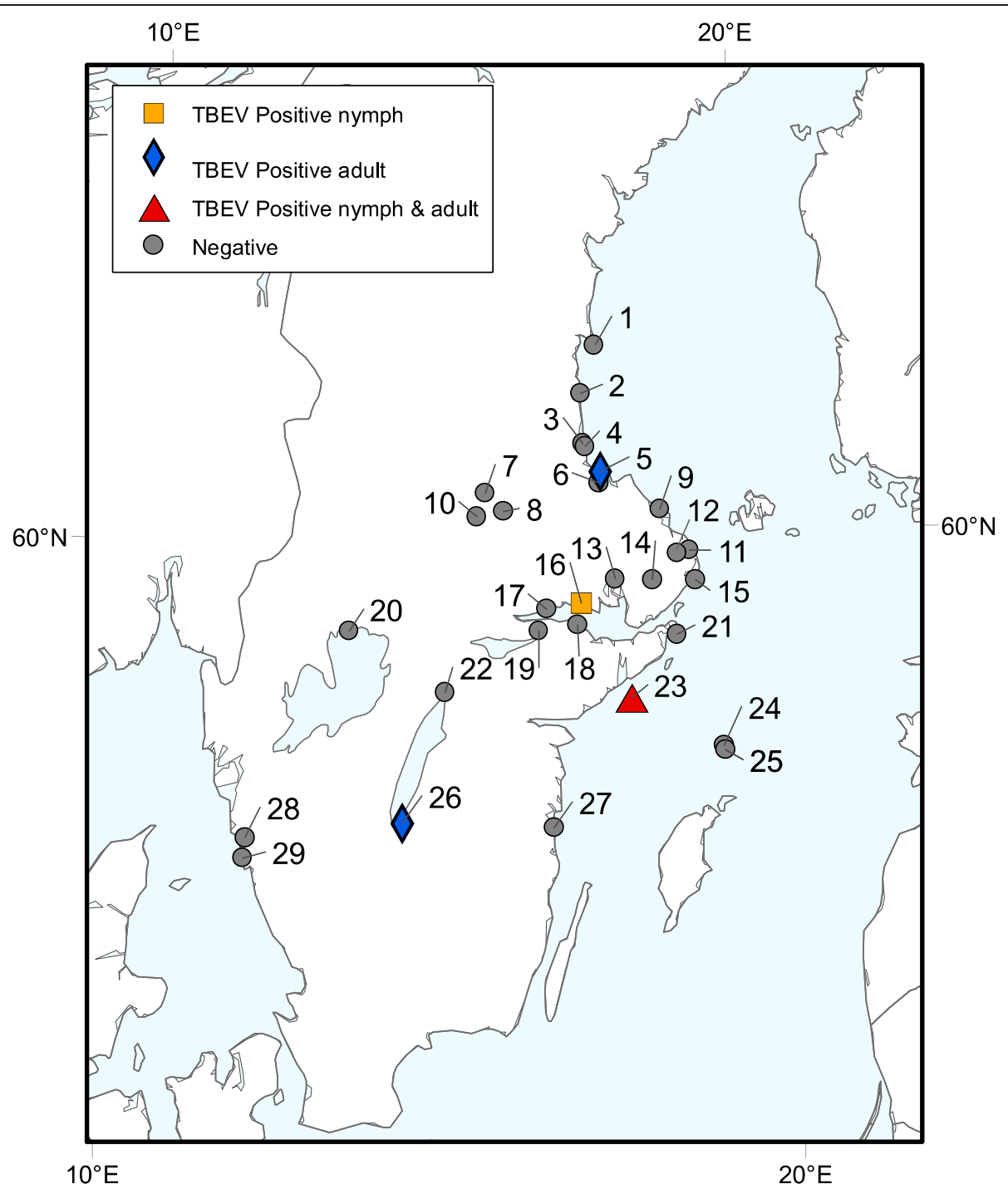

Figure 1 Map of southern and central Sweden. The numbers refer to localities where nymphs and adults of Ixodes ricinus ticks were collected. These ticks were subsequently analysed for TBEV infection. The name of each numbered locality and its GPS coordinates can be found in Table 1 and Additional file 1: Table S1, respectively.

of which were fully engorged, were removed from a pet dog (Canis lupus domesticus) (Table 1). All ticks were identified as I. ricinus based on morphological criteria according to $[41,42]$. The words "tick" and "ticks", when used in this article, denote I. ricinus.

\section{RNA extraction and detection of TBEV}

RNA was extracted, amplified and screened for TBEV in nymphs and adults of $I$. ricinus using a Real-Time Reverse Transcription Polymerase Chain Reaction (RTPCR) targeting a certain region in the 3 '-terminal of the TBEV genome modified after Schwaiger and Cassinotti [49] as previously described for the detection of TBEV in nymphs [50] and adult [29] Ixodes ticks, respectively. Each RNA extraction was made from a pool of $\sim 20$ nymphs, or a single adult tick, except for adult ticks collected at Gotska Sandön and Särö Västerskog, which were pooled as shown with the letter $\mathrm{P}$ in Table 1.

\section{Statistical analyses}

The prevalence of TBEV infection in I. ricinus ticks of a certain stage collected at a certain locality was estimated using the Minimum Infection Rate (MIR), i.e. the minimum infected proportion expressed as a percentage:

$$
\operatorname{MIR}=(\mathrm{p} / \mathrm{N}) \times 100 \%
$$

where:

$\mathrm{p}=$ the number of positive pools

$\mathrm{N}=$ the total number of ticks tested 
Table 1 Summary of published and unpublished data on I. ricinus ticks collected in Sweden, Norway, Finland and Denmark analysed for TBE virus infection

\begin{tabular}{|c|c|c|c|c|c|c|c|c|c|c|c|c|c|c|c|}
\hline \multirow[b]{2}{*}{ Country } & \multirow[b]{2}{*}{$\begin{array}{l}\text { Collection } \\
\text { year }\end{array}$} & \multirow[b]{2}{*}{ Locality } & \multicolumn{5}{|c|}{ Number of collected ticks } & \multicolumn{3}{|c|}{ Number of TBEV-positive } & \multicolumn{3}{|c|}{$\begin{array}{l}\text { Prevalence } \\
\text { estimate (\%) }\end{array}$} & \multirow[b]{2}{*}{ Method } & \multirow[b]{2}{*}{ Reference } \\
\hline & & & Nymphs & Males & Females & Total & Pools & $\begin{array}{l}\text { Positive } \\
\text { pools }\end{array}$ & $\begin{array}{l}\text { Positive } \\
\text { nymphs }\end{array}$ & $\begin{array}{l}\text { Positive } \\
\text { adults }\end{array}$ & $\begin{array}{c}\text { MIR } \\
\text { nymphs }\end{array}$ & $\begin{array}{l}\text { MIR } \\
\text { adults }\end{array}$ & $\begin{array}{l}\text { MIR } \\
\text { all }\end{array}$ & & \\
\hline Sweden & 1958 & $\begin{array}{l}96 \mathrm{~km} \mathrm{NE} \text { of Stockholm } \\
\text { (9 sites) }\end{array}$ & 35 & & 898 & 933 & 24 & 4 & 1 & 3 & 2.86 & 0.33 & 0.42 & $\left.M B\right|^{*}$ & [43] \\
\hline Sweden & 2003 & Torö & 106 & & 9 & 115 & 1 & 1 & - & - & - & - & 0.87 & RT-PCR & [17] \\
\hline Sweden & 2003 & $\begin{array}{l}\text { Combined central Sweden } \\
\text { (3 sites) }\end{array}$ & 167 & & 23 & 190 & 1 & 1 & - & - & - & - & 0.53 & RT-PCR & [17] \\
\hline Sweden & 2006 & $\begin{array}{l}3 \text { sites south of Vänern } \\
\text { (T1-T3) }\end{array}$ & 4380 & 220 & 220 & 4820 & 263 & 11 & 9 & 2 & 0.21 & 0.45 & 0.23 & RT-PCR & [29] \\
\hline Sweden & 2004 & South-western Sweden (T4) & 2740 & & 70 & 2810 & 144 & 7 & 6 & 1 & 0.22 & 1.43 & 0.25 & RT-PCR & [29] \\
\hline Sweden & 2008 & Hudiksvall (1) & 30 & 6 & 5 & 41 & 14 & 0 & 0 & 0 & 0 & 0 & 0 & RT-PCR & This study \\
\hline Sweden & 2008 & Stenö/Källskär (2) & 300 & 90 & 92 & 482 & 202 & 0 & 0 & 0 & 0 & 0 & 0 & RT-PCR & This study \\
\hline Sweden & 2008 & Gävle (3) & 4 & 1 & 0 & 5 & 2 & 0 & 0 & 0 & 0 & 0 & 0 & RT-PCR & This study \\
\hline Sweden & 2008 & Trödje (4) & 3 & 2 & 2 & 7 & 4 & 0 & 0 & 0 & 0 & 0 & 0 & RT-PCR & This study \\
\hline Sweden & 2008 & Skutskär (5) & 29 & 11 & 15 & 55 & 27 & 1 & 0 & 1 & 0 & 3.85 & 1.82 & RT-PCR & This study \\
\hline Sweden & 2008 & Älvkarleby (6) & 10 & 6 & 13 & 29 & 20 & 0 & 0 & 0 & 0 & 0 & 0 & RT-PCR & This study \\
\hline Sweden & 2008 & Borlänge (7) & 7 & 4 & 4 & 15 & 9 & 0 & 0 & 0 & 0 & 0 & 0 & RT-PCR & This study \\
\hline Sweden & 2008 & Vikmanshyttan (8) & 15 & 2 & 4 & 21 & 7 & 0 & 0 & 0 & 0 & 0 & 0 & RT-PCR & This study \\
\hline Sweden & 2008 & Östhammar $\left(9^{*}\right)$ & 94 & 10 & 15 & 119 & 31 & 0 & 0 & 0 & 0 & 0 & 0 & RT-PCR & This study \\
\hline Sweden & 2008 & Norbo Finnmark (10) & 11 & 11 & 12 & 34 & 24 & 0 & 0 & 0 & 0 & 0 & 0 & RT-PCR & This study \\
\hline Sweden & 2008 & Väddö $\left(11^{*}\right)$ & 32 & 10 & 6 & 48 & 18 & 0 & 0 & 0 & 0 & 0 & 0 & RT-PCR & This study \\
\hline Sweden & 2008 & Skebobruk $\left(12^{*}\right)$ & 40 & 13 & 19 & 72 & 34 & 0 & 0 & 0 & 0 & 0 & 0 & RT-PCR & This study \\
\hline Sweden & 2008 & Morga $\left(13^{*}\right)$ & 300 & 31 & 55 & 386 & 114 & 0 & 0 & 0 & 0 & 0 & 0 & RT-PCR & This study \\
\hline Sweden & 2008 & Rimbo $\left(14^{*}\right)$ & 8 & 2 & 4 & 14 & 7 & 0 & 0 & 0 & 0 & 0 & 0 & RT-PCR & This study \\
\hline Sweden & 2008 & Kapellskär (15*) & 373 & 59 & 70 & 502 & 151 & 0 & 0 & 0 & 0 & 0 & 0 & RT-PCR & This study \\
\hline Sweden & 2008 & Kolarvik $\left(16^{*}\right)$ & 158 & 57 & 49 & 264 & 115 & 1 & 1 & 0 & 0.63 & 0 & 0.38 & RT-PCR & This study \\
\hline Sweden & 2008 & Västerås (17*) & 137 & 11 & 24 & 172 & 47 & 0 & 0 & 0 & 0 & 0 & 0 & RT-PCR & This study \\
\hline Sweden & 2008 & Strängnäs (18*) & 37 & 27 & 22 & 86 & 51 & 0 & 0 & 0 & 0 & 0 & 0 & RT-PCR & This study \\
\hline Sweden & 2008 & Eskilstuna $\left(19^{*}\right)$ & 27 & 4 & 7 & 38 & 13 & 0 & 0 & 0 & 0 & 0 & 0 & RT-PCR & This study \\
\hline Sweden & 2008 & Karlstad (20) & 9 & 5 & 3 & 17 & 9 & 0 & 0 & 0 & 0 & 0 & 0 & RT-PCR & This study \\
\hline Sweden & 2008 & Värmdö $\left(21^{*}\right)$ & 46 & 3 & 6 & 55 & 16 & 0 & 0 & 0 & 0 & 0 & 0 & RT-PCR & This study \\
\hline Sweden & 2008 & Askersund (22) & 36 & 0 & 5 & 41 & 9 & 0 & 0 & 0 & 0 & 0 & 0 & RT-PCR & This study \\
\hline Sweden & 2008 & Herrhamra $\left(23^{*}\right)$ & 196 & 31 & 36 & 263 & 99 & 4 & 1 & 3 & 0.51 & 4.48 & 1.52 & RT-PCR & This study \\
\hline
\end{tabular}


Table 1 Summary of published and unpublished data on I. ricinus ticks collected in Sweden, Norway, Finland and Denmark analysed for TBE virus infection

\section{(Continued)}

\begin{tabular}{|c|c|c|c|c|c|c|c|c|c|c|c|c|c|c|c|}
\hline Sweden & 2008 & Kapellängen, GS (24) (P) & 24 & 21 & 2 & 47 & 25 & 0 & 0 & 0 & 0 & 0 & 0 & RT-PCR & This study \\
\hline Sweden & 2008 & Gamla gården, GS (25) (P) & 5 & 2 & 2 & 9 & 4 & 0 & 0 & 0 & 0 & 0 & 0 & RT-PCR & This study \\
\hline Sweden & 2008 & Jönköping (26) & 30 & 2 & 1 & 33 & 5 & 1 & 0 & 1 & 0 & 33.33 & 3.03 & RT-PCR & This study \\
\hline Sweden & 2008 & Västervik (27) & 14 & 4 & 5 & 23 & 10 & 0 & 0 & 0 & 0 & 0 & 0 & RT-PCR & This study \\
\hline Sweden & 2008 & Änggårdsbergen (28) & 31 & 0 & 1 & 32 & 3 & 0 & 0 & 0 & 0 & 0 & 0 & RT-PCR & This study \\
\hline Sweden & 2008 & Särö Västerskog (29) (P) & 68 & 0 & 2 & 70 & 8 & 0 & 0 & 0 & 0 & 0 & 0 & RT-PCR & This study \\
\hline Sweden & 2008 & $\begin{array}{l}\text { Combined central Sweden, } \\
12 \text { sites* }\end{array}$ & 1448 & 258 & 313 & 2019 & 258 & 5 & 2 & 3 & 0.14 & 0.53 & 0.25 & RT-PCR & This study \\
\hline Sweden & 2008 & Combined Sweden, 29 sites & 2074 & 425 & 481 & 2980 & 1074 & 7 & 2 & 5 & 0.10 & 0.55 & 0.23 & RT-PCR & This study \\
\hline Sweden & 1958-2008 & $\begin{array}{l}\text { Combined Sweden, } \\
4 \text { studies, } 45 \text { sites }\end{array}$ & 9396 & \multicolumn{2}{|c|}{2337} & 11733 & 1510 & 30 & 18 & 11 & 0.19 & 0.47 & 0.26 & $* / P C R$ & {$[17,29,43]$, this study } \\
\hline Finland & $\begin{array}{l}\text { 1957-1960, } \\
1964\end{array}$ & $\begin{array}{l}\text { Archipelago of southern- } \\
\text { western Finland }\end{array}$ & 4932 & 391 & 389 & 8131 & 249 & 18 & - & - & - & - & 0.22 & $\left.M B\right|^{* *}$ & [44] \\
\hline Finland & $\begin{array}{l}\text { 1957-1960, } \\
1964\end{array}$ & Southern Finland & 124 & 9 & 0 & 133 & 7 & 0 & - & - & - & - & 0 & $\left.M B\right|^{* *}$ & [44] \\
\hline Finland & $\begin{array}{l}\text { 1957-1960 } \\
1964\end{array}$ & South-eastern Finland & 1308 & 39 & 84 & 1643 & 51 & 1 & - & - & - & - & 0.06 & $\left.M B\right|^{* *}$ & [44] \\
\hline Finland & 1996-1997 & Isosaari (Mjölö) island, Helsinki & 69 & \multicolumn{2}{|c|}{70} & 139 & 20 & 1 & - & - & - & - & 0.72 & RT-PCR & [45] \\
\hline Finland & 1996-1997 & Åland islands & 203 & \multicolumn{2}{|c|}{247} & 450 & 48 & 1 & - & - & - & - & 0.22 & RT-PCR & [45] \\
\hline Finland & 1996-1997 & Helsinki city parks & 74 & \multicolumn{2}{|c|}{123} & 726 & 130 & 0 & - & - & - & - & 0 & RT-PCR & [45] \\
\hline Finland & 2004 & $\begin{array}{c}\text { Kokkola (Karleby) archipelago } \\
\text { (10 sites) }\end{array}$ & 72 & 539 & 570 & 1181 & 122 & 13 & - & - & - & - & 1.10 & RT-PCR & [13] \\
\hline Finland & 2003 & Kumlinge & - & - & - & 454 & 46 & 4 & - & - & - & - & 0.88 & RT-PCR & [21] \\
\hline Finland & 2005 & Isosaari (Mjölö) island, Helsinki & - & - & - & 96 & 11 & 1 & - & - & - & - & 1.04 & RT-PCR & [21] \\
\hline Finland & 2007 & Turku (Åbo) archipelago & - & - & - & 1039 & 315 & 1 & - & - & - & - & 0.10 & RT-PCR & [21] \\
\hline Finland & 2005 & Lappeenranta (Villmanstrand) & - & - & - & 292 & 29 & 2 & - & - & - & - & 0.68 & RT-PCR & [21] \\
\hline Finland & 2008 & Närpiö (Närpes) & - & - & - & 36 & - & 0 & - & - & - & - & 0 & RT-PCR & [21] \\
\hline Finland & $1957-2008$ & $\begin{array}{l}\text { Combined Finland, } \\
4 \text { studies, } \geq 27 \text { sites }\end{array}$ & & & & 14320 & 2490 & 42 & - & - & - & - & 0.29 & $* * / P C R$ & {$[13,21,44,45]$} \\
\hline Norway & 2003 & $\begin{array}{l}\text { Vest-Agder and Hordaland } \\
\text { county }\end{array}$ & & 360 & & & & 1 & - & - & - & - & 0.28 & RT-PCR & [19] \\
\hline Norway & 2004 & $\begin{array}{l}\text { Vest-Agder and Hordaland } \\
\text { county }\end{array}$ & & 450 & & & & 1 & - & - & - & - & 0.22 & RT-PCR & [19] \\
\hline Norway & 2009 & Risør, Dalen (S1) & 900 & - & - & 900 & 90 & 1 & 1 & - & 0.11 & - & 0.11 & RT-PCR & [46] \\
\hline Norway & 2009 & Arendal (S2-S3) & 1350 & - & - & 1350 & 135 & 8 & 8 & - & 0.59 & - & 0.59 & RT-PCR & {$[46]$} \\
\hline Norway & 2009 & Mandal (\$4-S5) & 1520 & - & - & 1520 & 152 & 9 & 9 & - & 0.59 & - & 0.59 & RT-PCR & {$[46]$} \\
\hline
\end{tabular}


Table 1 Summary of published and unpublished data on I. ricinus ticks collected in Sweden, Norway, Finland and Denmark analysed for TBE virus infection (Continued)

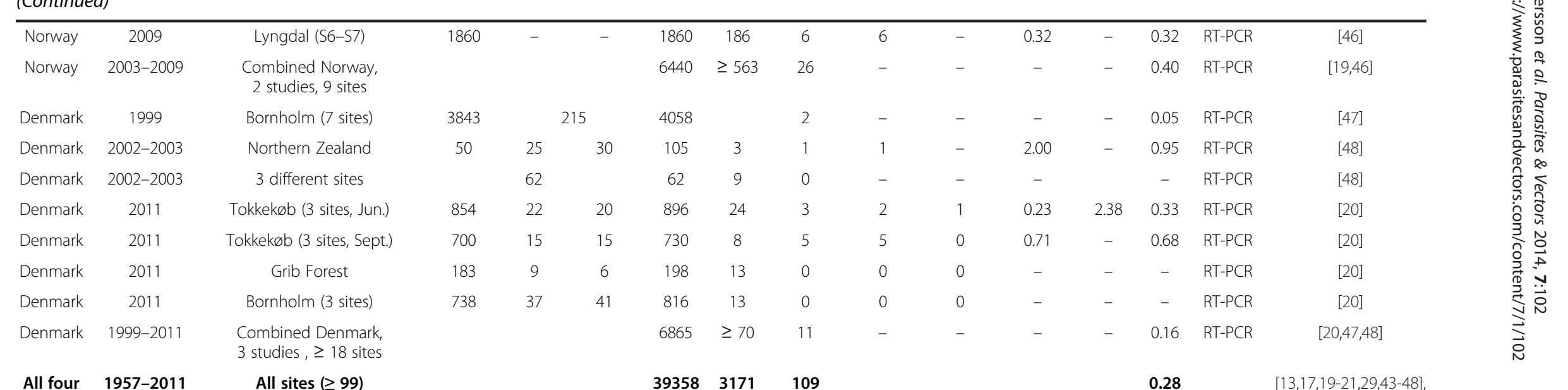

$\begin{array}{ccc}\text { All four } & 1957-2011 \quad \text { All sites }(\geq 99) \\ \text { countries } & & \end{array}$

$39358 \quad 3171 \quad 109$

0.28

this study
the

Numbers within parenthesis for the present study correspond to sampling localities in Figure 1.

MIR, Minimum Infection Rate (\%). P, adult ticks were pooled.

$M \mathrm{MI}^{*}$, Mouse brain inoculation and tissue cultures followed by neutralization tests and complement fixation tests [43].

$\mathrm{MB}^{* *}$, Mouse brain inoculation followed by haemagglutination and haemagglutination-inhibition tests [44]. 
The MIR is considered acceptable for the present type of data on arboviruses occurring in their vector populations at low prevalences [51-53]. This method assumes that only one infected tick is present in each positive pool [51]. The MIR also permits comparison of prevalence estimates from different investigations in which different tick collection strategies were used, and where the number of positive pools and the total number of ticks analysed are known. Fisher's exact test was used to test if there is a significant difference, based on a twotailed hypothesis, between two MIR estimates.

\section{Gathering of TBEV prevalence data from previous studies}

TBEV prevalence data were included in our review if the study reported at least the total number of ticks and/or tick stage(s) collected, and the total number of TBEV positive pools and/or individual ticks. We included only publications presenting TBEV-analyses of ticks collected in Denmark, Finland, Norway or Sweden.

\section{Results}

TBEV in nymphs or adult ticks in Sweden

A total of 2,074 nymphs and 906 adults of I. ricinus were collected from 29 study localities in Sweden during 2008 (Figure 1). Among 108 pools of nymphs tested two pools were TBEV-positive, as indicated by RT-PCR (Table 1): One pool originated from Kolarvik and the other from Herrhamra. Five of 906 adult ticks tested individually were TBEV-positive by RT-PCR (Figure 1, Table 1): One tick originated from Jönköping, three ticks from Herrhamra on the island of Torö, and one from Skutskär. The MIR calculated was $0.10 \%$ for the nymphs and $0.55 \%$ for the adult females (Fisher's test: $\mathrm{P}=0.030$ ). Four of $7 \mathrm{TBEV}-$ positive ticks originated from the same small island, Torö, which is a well-known TBEV-endemic focus. At Torö, we detected the TBEV infection in both nymphs (MIR = $0.51 \%)$ and adults of both sexes $(\mathrm{MIR}=4.48 \%)$ of $\mathrm{I}$. ricinus (Fisher's test: $\mathrm{P}=0.0521$ ).

Based on all nymphs and adults of I. ricinus from the 29 localities the TBEV prevalence, calculated as a MIR, was $0.23 \%$ (7 positive pools; 1,007 negative pools; $\mathrm{N}=2,980$ ticks analysed). For ticks collected in the northern part of southern Sweden (Eskilstuna, Herrhamra, Kapellskär, Kolarvik, Morga, Rimbo, Skebobruk, Strängnäs, Väddö, Värmdö, Västerås, Östhammar) (Figure 1, Table 1), the MIR was $0.25 \%$. This infection prevalence comes from 5 positive pools ( 2 nymphal pools and 3 adult ticks; 84 negative nymphal pools and 568 negative specimens) out of 2,019 ticks tested (1,448 nymphs and 571 adults).

\section{TBEV in ticks from the four countries}

The overall mean MIR estimate for TBEV in I. ricinus for the four neighbouring countries, Denmark, Sweden Norway and Finland, was 0.28\% (109 TBEV-positive pools of 39,358 ticks tested, Table 1), which corresponds to approximately one TBEV-positive tick in each sample of 360 ticks. However, it should be noted that this is an overall mean MIR for the four countries and is based on both nymphs and adult ticks. The reason for combining these life stages is that in several of the publications analysed information about the tick stage(s) analysed was not stated. In the total data set (Table 1), the nymphal to adult ratio is approximately 5:1. This is within the range of the ratio of nymphs to adults that can be found in research on population ecology of I. ricinus [40,54-56].

\section{Discussion}

\section{TBEV prevalence in Sweden and neighbouring Nordic} countries

The overall mean TBEV prevalence for $I$. ricinus in the four Scandinavian countries was $0.28 \%$. This corresponds to almost one TBEV-positive specimen in each sample of 360 ticks collected. It should be emphasised that the latter percentage, $0.28 \%$, for Scandinavia refers to a mixture of pools containing both nymphs and adult ticks. It is well known that the infection prevalence of adult female ticks is usually significantly higher than that of nymphs [57]. This is most likely mainly due to the fact that, during their development from larva to adult tick, the questing adult tick female has usually blood-fed twice, i.e. on two different, potentially TBEV-infected host individuals. In contrast, the questing nymphs have fed only once $[58,59]$. This is also indicated in the present study by the data from Herrhamra where the MIR was $0.51 \%$ for nymphs and $4.48 \%$ for adults. Thus, if we had analysed relatively more adult ticks from Herrhamra it is likely that the overall TBEV infection prevalence estimate would have appeared even higher. The estimated mean TBEV prevalence is similar to those estimated for another $I$. ricinus-transmitted pathogen, $B$. miyamotoi, in Sweden [60] and Estonia [50] but lower than those usually recorded for other pathogens vectored by $I$. ricinus, such as $B$. afzelii, B. garinii and $B$. valaisiana [37,60], and A. phagocytophilum [34,35,39,61].

The estimated infection prevalence increased when the TBEV analysis was restricted to ticks collected only from one locality, Herrhamra on the island of Torö. This is a well-known TBEV-enzootic area, where many people have contracted neuroinvasive TBE. The island seems to be an example of such a focus, as described by Dobler and coworkers [33] in which the TBEV occurs permanently within a restricted geographical area. Consequently, if a larger number of ticks had been collected outside of the TBEV focus and had been included in the virological analysis the TBEV prevalence estimate would have been reduced. Furthermore, another obvious problem with the use of the MIR estimate on pooled samples occurs when ticks are collected in a habitat where the infection rate is 
relatively high. Here, several virus-infected tick specimens could be present in one pool; yet, such a positive pool would be considered to contain only one infected tick, thereby reducing the prevalence estimate to fall below the actual prevalence [51-53].

\section{Maintenance of TBEV in nature}

The TBE virus is maintained and transmitted in natural foci mainly in five ways: (i) by ticks becoming infected when feeding on viraemic hosts whereby infective ticks, in a subsequent stage, may transmit the virus to susceptible, new hosts; (ii) by transovarial transmission in ticks; (iii) by transstadial transmission in ticks; (iv) by sexual transmission from a male tick to a female tick; and (v) by non-viraemic transmission from infective tick(s) cofeeding adjacent to susceptible ticks on a non-infected and/or non-viraemic host [62-65].

Transmission of the TBEV can take place when tick larvae or nymphs feed on (I) viraemic Apodemus mice or Myodes voles. Apodemus mice are regarded as the optimal transmission hosts for this mode of TBEV transfer, since they do not rapidly become resistant to the feeding ticks [66]. This is in contrast to bank voles, which rapidly become resistant to the feeding ticks [67]. Furthermore, it is generally accepted that any viraemia in rodents, infective to feeding ticks, will only last for a few days. Therefore, this mode of TBEV transmission is not considered sufficiently effective to solely maintain the virus in the $I$. ricinus populations $[65,68,69]$. Still, rodents can act as TBEV reservoirs since TBEV can be detected in infected rodents for periods of several months, including during the winter period [70,71].

Even ticks act as reservoirs for the TBEV due to their capacity of transovarial and transstadial transmission. Once infected, the tick will usually remain infected throughout its life [65]. However, transovarial transmission only occurs at a low frequency and is, therefore, on its own considered not sufficiently effective to maintain TBEV in the vector population [72]. Sexual transmission occurs when TBEV-infected tick males infect females by transferring infectious saliva and/or seminal fluid during copulation [73]. It is not known if transovarial and sexual transmission are necessary for the long-term persistence of the virus in the ecosystem. Possibly, they may have evolved to function as auxiliary modes of transmission by which the TBEV can 'survive' in the ecosystem during periods when the availability of vertebrate virus transmission hosts and vertebrate virus reservoirs are unavailable for the questing ticks to feed on. Non-viraemic transmission is generally regarded as the main mode of transmission by which TBEV is transmitted to infectible ticks and maintained in nature. Non-viraemic transmission may occur when one or more susceptible ticks are feeding in close proximity to an infective tick $[62,65,68,74]$. In this way, transmission of TBEV takes place when infective ticks, typically nymphs, are feeding on the host. TBE virions will be transferred with the saliva, which is injected by the blood-feeding, virus-infective nymphs into the feeding site. Here, virions may be phagocytosed by leukocytes. Some of these virus-infected blood cells may then be ingested by susceptible ticks, typically larvae, which in this manner become infected [62]. It should be noted that for virus transmission to occur among co-feeding ticks it is not necessary that a viraemia is present in the host [63]. However, synchronous questing activity of infective ticks and susceptible ticks is necessary for the TBE virus to be transmitted in this way [75]. Non-viraemic transmission supported by a low degree of transovarial transmission is considered sufficient to maintain the TBEV at the prevalence levels at which it generally occurs in I. ricinus [76].

There is some evidence that goats are not competent hosts either for viraemic or non-viraemic transmission of TBEV among co-feeding ticks [77]. However, to our knowledge, there exists no experimental evidence that cervids are incompetent hosts for non-viraemic transmission of TBEV among co-feeding ticks. Although the TBEV viraemia in deer may be of a short duration and of insufficient magnitude in cervids we should not yet reject the possibility that co-feeding transmission via non-viraemic cervids might take place. In TBE-endemic areas both domesticated and wild ungulates, especially roe deer, usually have antibodies to TBEV [78] and the seroprevalence in TBEV foci can be high in such mammals [77]. Labuda and co-workers demonstrated that natural hosts, which have neutralizing antibodies to the TBEV and apparently are immune to TBEV (i.e., without any viraemia) still can support transmission of this virus from infective to uninfected ticks feeding close together on the same host [63]. All stages of I. ricinus preferentially attach to the neck and head region of roe deer and both larvae and nymphs occur at the highest densities on the head of this important tick maintenance host [79]. These facts support the idea that the roe deer is one of the most important host species for adult I. ricinus ticks. These facts also support the notion that roe deer possibly can support the non-viraemic transmission of TBEV to uninfected ticks. Indeed, roe deer abundance may be a useful indicator of the risk for people in TBEV-endemic areas to contract a TBE virus infection. Along these lines, Zeman and Januska [80] showed that the risk of TBE was associated with the abundance of roe deer and mice (Apodemus spp.).

\section{Is the TBEV prevalence in the tick population unexpectedly low?}

Two important questions are: (I) Is the infection prevalence of TBEV in the I. ricinus populations exceptionally low? (II) How can the virus persist in nature despite 
such 'low' infection prevalence? Prevalence rates of TBEV in $I$. ricinus populations in endemic areas usually range from $0.1-5 \%[7,10,57,81]$ and the prevalence usually fluctuates from year to year and among regions [57]. It is likely that both viraemic and non-viraemic transmission of TBEV to uninfected ticks occur more frequently during years of peak abundance of small mammals [27]. So these fluctuations in TBEV infection prevalence are presumably to some degree due to the varying densities of reservoir-competent vs. reservoirincompetent tick hosts. Both TBEV and B. miyamotoi seem to have geographical distributional ranges composed of a patchwork of relatively small enzootic foci. Here, both pathogens seem to be present at low prevalences in their invertebrate reservoir and vector, i.e. $I$. ricinus. Both pathogens rely, to a small extent, on transovarial transmission. It might be a trait, which has evolved in TBEV and in B. miyamotoi, to enable these human pathogens to 'survive' independent from vertebrate transmission hosts during periods when the availability of such tick hosts, i.e. small mammals, is low or non-existent.

One reason for the low apparent prevalence recorded in many investigations may be due to inclusion of ticks from non-endemic areas adjacent to the relatively confined TBEV-infected foci [33]. If the limits of such a focus are known and ticks are collected only from within the borders of this TBEV focus, the virological analysis of these ticks is likely to give a higher TBEV prevalence estimate than if ticks from outside the TBE focus were included in the analysis.

It has been known for many years that TBEV infection rates of blood-fed ticks, collected from humans or other hosts, are usually higher than those of unfed, questing ticks collected from the vegetation in the same area $[81,82]$. In a series of experiments, it was shown that TBEV-infected ticks become more active in their hostsearching behaviour compared to that of uninfected ticks $[83,84]$. It was also suggested that TBEV might occur in undetectable concentrations in infected ticks in nature, and that it is not until the tick is feeding, that virus quantities can increase 100 -fold [83] so that TBEV becomes detectable [84]. It may be that the virus occurs in an undetectable, seemingly 'latent' state, in the hostseeking TBEV-infected tick. Components in the blood and/or the increased temperature might be triggering immature virions to become mature virions. Another possibility is that the amount of virions in the nonblood-fed tick is below the detection limit of the methodology ordinarily used. Different methods for detecting viruses and microorganisms can have different sensitivities $[85,86]$. Thus, it has been emphasized that if the sensitivity of the PCR-based detection method used is not optimal, it is likely that the infection prevalence will be underestimated [57]. The PCR method that we used, which is a modification of the method described by Schwaiger and Cassinotti [49], has a detection limit of 1-10 copies per reaction. Therefore, the TBEV prevalences of the ticks collected in Sweden and analysed by us, are most likely not underestimated.

The observed, relatively low TBEV prevalence in $I$. ricinus in nature is likely explained by a combination of such factors as just mentioned. Future studies should aim to explain in more detail the relative importance of the different environmental, pathogen-, tick-, and vertebraterelated factors, which are necessary for an area to be a long-term TBEV enzootic focus.

\section{Conclusions}

If the ratio of nymphs to adult ticks in the TBEV-analysed sample differs from that in the I. ricinus population in the field, the MIR obtained will not necessarily reflect the TBEV prevalence in the field. The relatively low TBEV prevalence in the potential vector population recorded in most studies may partly be due to: (i) inclusion of uninfected ticks from the 'uninfected areas' surrounding the TBEV endemic foci; (ii) inclusion of an unrepresentative, too large proportion of immature ticks, compared to adult ticks, in the analysed tick pools; and (iii) shortcomings in the laboratory techniques used to detect the virus that may be present in a very low concentration or undetectable state in ticks which have not recently fed.

\section{Additional file}

Additional file 1: Table S1. Name and GPS coordinates for each locality where ticks were collected. Numbers refer to the same numbers in Figure 1 and Table 1. P = adult ticks were pooled.

\section{Competing interests}

The authors declare that they have no competing interests.

\section{Authors' contributions}

JP and TJ collected, reviewed, analysed and synthesised published and unpublished information for this article; JP and TJ wrote the initial and final versions of the manuscript. JP and TJ collected ticks in the field that were analysed for TBEV infection by JP, IG and SV in the laboratory of the Public Health Agency of Sweden (formerly the Swedish Institute for Communicable Disease Control), Solna, Sweden. All co-authors co-revised the manuscript and co-refined the intellectual content of the manuscript. All authors read and approved the final version of the manuscript.

\section{Acknowledgements}

We are grateful to Allison Perrigo, Uppsala University, for many valuable suggestions on the manuscript; to Isabella Fröjdman, Helsingfors University, for invaluable assistance with collection of ticks; and to Anders Larsson for help with constructing the map. TJ's and JP's research on ticks and tick-borne infections is funded by Carl Trygger's Stiftelse, Helge Ax:son Johnson's stiftelse, Längmanska Kulturfonden, Magnus Bergvall's Stiftelse and Stiftelsen Lars Hierta's Minne (all in Stockholm, Sweden); IG's research is funded by the Estonian Ministry of Education and Research (project SF0940033s09)

This article is an extended, revised version of an article published as part of a PhD dissertation at Uppsala University. The thesis was publicly examined on 
$10^{\text {th }}$ January 2014 for the degree of Doctor of Philosophy. The full reference of the PhD thesis is:

Pettersson, J. H.-O. 2013. The origin of the genus Flavivirus and the ecology of tick-borne pathogens. Digital Comprehensive Summaries of Uppsala Dissertations from the Faculty of Science and Technology 1100. 60 pp. Uppsala: Acta Universitatis Upsaliensis. ISBN 978-91-554-8814-7.

\section{Author details}

${ }^{1}$ Medical Entomology Unit, Subdepartment of Systematic Biology, Department of Organismal Biology, Evolutionary Biology Centre, Uppsala University, Norbyvägen 18d, SE-752 36, Uppsala, Sweden. ${ }^{2}$ Department of Virology, National Institute for Health Development, Tallinn, Estonia. ${ }^{3}$ Public Health Agency of Sweden, Solna, Sweden.

Received: 2 January 2014 Accepted: 16 February 2014 Published: 11 March 2014

\section{References}

1. Granström M: Tick-borne zoonoses in Europe. Clin Microbiol Infect 1997, 3:156-169.

2. Charrel RN, Attoui H, Butenko AM, Clegg JC, Deubel V, Frolova TV, Gould EA, Gritsun TS, Heinz FX, Labuda M, Lashkevich VA, Loktev V, Lundkvist A, Lvov DV, Mandl CW, Niedrig M, Papa A, Petrov VS, Plyusnin A, Randolph S, Süss J, Zlobin VI, de Lamballerie X: Tick-borne virus diseases of human interest in Europe. Clin Microbiol Infect 2004, 10:1040-1055.

3. Gritsun TS, Nuttall PA, Gould EA: Tick-borne flaviviruses. Adv Virus Res 2003, 61:317-371

4. International Committee on Taxonomy of Viruses: Virus Taxonomy. In. 2012. Release. Available: http://ictvonline.org/virusTaxonomy.asp? version=2012 Accessed on: 2013-04-22.

5. Gritsun TS, Lashkevich VA, Gould EA: Tick-borne encephalitis. Antiviral Res 2003, 57:129-146.

6. European Centre for Disease Prevention and Control: Epidemiological situation of tick-borne encephalitis in the European Union and European Free Trade Association countries. ECDC 2012: . doi: 10.2900/62311. Available: http://ecdc.europa.eu/en//publications/publications/tbe-in-eu-efta. pdf.

7. Süss J: Tick-borne encephalitis, epidemiology, risk areas, and virus strains in Europe and Asia-an overview. Ticks Tick Borne Dis 2010, 2011(2):2-15.

8. Wu X-B, Na RH, Wei S-S, Zhu J-S, Peng H-J: Distribution of tick-borne diseases in China. Parasit Vectors 2013, 6:119.

9. Ecker M, Allison SL, Meixner T, Heinz FX: Sequence analysis and genetic classification of tick-borne encephalitis viruses from Europe and Asia. J Gen Virol 1999, 80(Pt 1):179-185.

10. Katargina O, Russakova S, Geller J, Kondrusik M, Zajkowska J, Zygutiene M, Bormane A, Trofimova J, Golovljova I: Detection and characterization of tick-borne encephalitis virus in Baltic countries and eastern Poland. PLOS ONE 2013, 8:e61374.

11. Kovalev SY, Kokorev VS, Belyaeva IV: Distribution of Far-Eastern tick-borne encephalitis virus subtype strains in the former Soviet Union. J Gen Virol 2010, 91:2941-2946.

12. Kovalev SY, Chernykh DN, Kokorev VS, Snitkovskaya TE, Romanenko W: Origin and distribution of tick-borne encephalitis virus strains of the Siberian subtype in the Middle Urals, the north-west of Russia and the Baltic countries. J Gen Virol 2009, 90(Pt 12):2884-2892.

13. Jääskeläinen $A E$, Tikkakoski T, Uzcategui NY, Alekseev AN, Vaheri A, Vapalahti O: Siberian subtype tick-borne encephalitis virus, Finland. Emerg Infect Dis 2006, 12:1568-1571.

14. Lundkvist $\AA$, Vene S, Golovljova I, Mavtchoutko V, Forsgren M, Kalnina V, Plyusnin A: Characterization of tick-borne encephalitis virus from Latvia: evidence for co-circulation of three distinct subtypes. J Med Virol 2001 65:730-735

15. Golovljova I, Vene S, Sjölander KB, Vasilenko V, Plyusnin A, Lundkvist A: Characterization of tick-borne encephalitis virus from Estonia. J Med Virol 2004, 74:580-588.

16. Haglund M, Vene S, Forsgren M, Günther G, Johansson B, Niedrig M, Plyusnin $A$, Lindquist $L$, Lundkvist $A$ : Characterisation of human tick-borne encephalitis virus from Sweden. J Med Virol 2003, 71:610-621.

17. Melik W, Nilsson AS, Johansson M: Detection strategies of tick-borne encephalitis virus in Swedish Ixodes ricinus reveal evolutionary characteristics of emerging tick-borne flaviviruses. Arch Virol 2007, 152:1027-1034.

18. Norberg P, Roth A, Bergström T: Genetic recombination of tick-borne flaviviruses among wild-type strains. Virology 2013, 440:105-116.

19. Skarpaas T, Golovljova I, Vene S, Ljøstad U, Sjursen H, Plyusnin A, Lundkvist A: Tickborne encephalitis virus, Norway and Denmark. Emerging Infect Dis 2006, 12:1136-1138.

20. Fomsgaard A, Fertner ME, Essbauer S, Nielsen AY, Frey S, Lindblom P, Lindgren P-E, Bødker R, Weidmann M, Dobler G: Tick-borne encephalitis virus, Zealand, Denmark, 2011. Emerging Infect Dis 2013, 19:1171-1173.

21. Jääskeläinen $A E$, Sironen T, Murueva GB, Subbotina N, Alekseev AN, Castrén J, Alitalo I, Vaheri A, Vapalahti O: Tick-borne encephalitis virus in ticks in Finland, Russian Karelia and Buryatia. J Gen Virol 2010, 91(Pt 11):2706-2712

22. Jääskeläinen $A E$, Tonteri $E$, Sironen $T$, Pakarinen $L$, Vaheri $A$, Vapalahti $O$ : European subtype tick-borne encephalitis virus in Ixodes persulcatus ticks. Emerging Infect Dis 2011, 17:323-325.

23. Kaiser R: Tick-borne encephalitis. Infect Dis Clin North Am 2008, 22:561-575.

24. Lindquist L, Vapalahti O: Tick-borne encephalitis. Lancet 2008, 371:1861-1871.

25. Mansfield KL, Johnson N, Phipps LP, Stephenson JR, Fooks AR, Solomon T: Tick-borne encephalitis virus-a review of an emerging zoonosis. J Gen Virol 2009, 90(Pt 8):1781-1794.

26. Holmgren EB, Forsgren M: Epidemiology of tick-borne encephalitis in Sweden 1956-1989: a study of 1116 cases. Scand J Infect Dis 1990, 22:287-295

27. Jaenson TGT, Hjertqvist M, Bergström $T$, Lundkvist $A$ : Why is tick-borne encephalitis increasing? A review of the key factors causing the increasing incidence of human TBE in Sweden. Parasit Vectors 2012, 5:184.

28. Jaenson TGT, Jaenson DGE, Eisen L, Petersson E, Lindgren E: Changes in the geographical distribution and abundance of the tick Ixodes ricinus during the past 30 years in Sweden. Parasit Vectors 2012, 5:8

29. Brinkley C, Nolskog P, Golovljova I, Lundkvist $\AA$, Bergström T: Tick-borne encephalitis virus natural foci emerge in western Sweden. Int J Med Microbiol 2008, 298, Supplement 1:73-80

30. Blaskovic D, Nosek J: The ecological approach to the study of tick-borne encephalitis. Prog Med Virol 1972, 14:275-320.

31. Nosek J, Kožuch O, Mayer V: Spatial distribution and stability of natural foci of tick-borne encephalitis virus in Central Europe. In Beiträge zur Geoökologie der Zentraleuropäischen Zecken-Encephalitis. Edited by Jusatz HJ. Berlin, Heidelberg: Springer Berlin Heidelberg; 1978:60-74.

32. Kupča AM, Essbauer S, Zoeller G, de Mendonça PG, Brey R, Rinder M, Pfister K, Spiegel M, Doerrbecker B, Pfeffer M, Dobler G: Isolation and molecular characterization of a tick-borne encephalitis virus strain from a new tick-borne encephalitis focus with severe cases in Bavaria, Germany. Ticks Tick Borne Dis 2010, 1:44-51.

33. Dobler G, Hufert F, Pfeffer M, Essbauer S: Tick-borne encephalitis: From microfocus to human disease. In Progress in Parasitology. Edited by Mehlhorn H. Berlin, Heidelberg: Springer Berlin Heidelberg; 2011:323-331.

34. Skarphédinsson S, Lyholm BF, Ljungberg M, Søgaard P, Kolmos HJ, Nielsen LP: Detection and identification of Anaplasma phagocytophilum, Borrelia burgdorferi, and Rickettsia helvetica in Danish Ixodes ricinus ticks. APMIS 2007, 115:225-230.

35. Stuen S, Granquist EG, Silaghi C: Anaplasma phagocytophilum-a widespread multi-host pathogen with highly adaptive strategies. Front Cell Infect Microbiol 2013, 3:31. doi:10.3389/fcimb.2013.0031.

36. Hubálek Z, Halouzka J: Distribution of Borrelia burgdorferi sensu lato genomic groups in Europe, a review. Eur J Epidemiol 1997, 13:951-957.

37. Blaschitz M, Narodoslavsky-Gföller M, Kanzler M, Walochnik J, Stanek G: Borrelia burgdorferi sensu lato genospecies in questing Ixodes ricinus ticks in Austria. Int J Med Microbiol 2008, 298:168-176.

38. Parola P, Paddock CD, Socolovschi C, Labruna MB, Mediannikov O, Kernif T, Abdad MY, Stenos J, Bitam I, Fournier P-E, Raoult D: Update on tick-borne rickettsioses around the world: a geographic approach. Clin Microbiol Rev 2013, 26:657-702.

39. Wallménius K, Pettersson JH-O, Jaenson TGT, Nilsson K: Prevalence of Rickettsia spp., Anaplasma phagocytophilum, and Coxiella burnetii in adult Ixodes ricinus ticks from 29 study areas in central and southern Sweden. Ticks Tick Borne Dis 2012, 3:100-106.

40. Mejlon HA, Jaenson TGT: Seasonal prevalence of Borrelia burgdorferi in Ixodes ricinus in different vegetation types in Sweden. Scand J Infect Dis 1993, 25:449-456.

41. Arthur DR: British Ticks. London: Butterworths; 1963. 
42. Filippova NA: Fauna of the SSSR, Paukoobraznye: Arachnidea. Ixodid ticks of subfamily Ixodinae, Volume 4(4). Russian: Leningrad: Nauka; 1977.

43. Von Zeipel G: Isolation of viruses of the Russian spring summer encephalitis-louping ill group from Swedish ticks and from a human case of meningoencephalitis. Arch Gesamte Virusforsch 1959, 9:460-469.

44. Brummer-Korvenkontio M, Saikku P, Korhonen P, Oker-Blom N: Arboviruses in Finland: I: isolation of tick-borne encephalitis (TBE) virus from arthropods, vertebrates, and patients. Am J Trop Med Hyg 1973, 22:382-389.

45. Han X, Aho M, Vene S, Peltomaa M, Vaheri A, Vapalahti O: Prevalence of tick-borne encephalitis virus in Ixodes ricinus ticks in Finland. J Med Virol 2001, 64:21-28.

46. Andreassen A, Jore $\mathrm{S}$, Cuber $\mathrm{P}$, Dudman $\mathrm{S}$, Tengs $\mathrm{T}$, Isaksen $\mathrm{K}$, Hygen $\mathrm{HO}$, Viljugrein H, Anestad G, Ottesen P, Vainio K: Prevalence of tick borne encephalitis virus in tick nymphs in relation to climatic factors on the southern coast of Norway. Parasit Vectors 2012, 5:177.

47. Jensen PM: Tætheder af skovflåten (Ixodes ricinus) og koeksistens af Louping ill-virus og tick borne encephalitis-virus på Bornholm. Ugeskr Laeger 2004, 166:2563-2565.

48. Fomsgaard A, Christiansen C, Bodker R: First identification of tick-borne encephalitis in Denmark outside of Bornholm, August 2009. Euro Surveil 2009, 14:36. Available online: http://www.eurosurveillance.org/ViewArticle. aspx?Articleld=19325

49. Schwaiger $M$, Cassinotti P: Development of a quantitative real-time RT-PCR assay with internal control for the laboratory detection of tick borne encephalitis virus (TBEV) RNA. J Clin Virol 2003, 27:136-145.

50. Geller J, Nazarova L, Katargina O, Leivits A, Järvekülg L, Golovljova I: Tick-borne pathogens in ticks feeding on migratory passerines in western part of Estonia. Vector Borne Zoonotic Dis 2013, 13:443-448.

51. Cowling DW, Gardner IA, Johnson WO: Comparison of methods for estimation of individual-level prevalence based on pooled samples. Prev Vet Med 1999, 39:211-225.

52. Speybroeck N, Williams CJ, Lafia KB, Devleesschauwer B, Berkvens D: Estimating the prevalence of infections in vector populations using pools of samples. Med Vet Entomol 2012, 26:361-371.

53. Ebert TA, Brlansky R, Rogers M: Reexamining the pooled sampling approach for estimating prevalence of infected insect vectors. Ann Entomol Soc Am 2010, 103:827-837.

54. Randolph SE, Green RM, Hoodless AN, Peacey MF: An empirical quantitative framework for the seasonal population dynamics of the tick Ixodes ricinus. Int J Parasitol 2002, 32:979-989.

55. Tälleklint L, Jaenson TG: Infestation of mammals by Ixodes ricinus ticks (Acari: Ixodidae) in south-central Sweden. Exp Appl Acarol 1997, 21:755-771.

56. Dobson ADM, Finnie TJR, Randolph SE: A modified matrix model to describe the seasonal population ecology of the European tick Ixodes ricinus: Ixodes ricinus population model. J Appl Ecol 2011, 48:1017-1028.

57. Süss J, Schrader C, Abel U, Voigt WP, Schosser R: Annual and seasonal variation of tick-borne encephalitis virus (TBEV) prevalence in ticks in selected hot spot areas in Germany using a nRT-PCR: results from 1997 and 1998. Zentralb/ Bakteriol 1999, 289:564-578.

58. Milne A: The ecology of the sheep tick, Ixodes ricinus L. Parasitology 1950 40:35-45.

59. Needham GR, Teel PD: Off-host physiological ecology of ixodid ticks. Annu Rev Entomol 1991, 36:659-681.

60. Fraenkel C-J, Garpmo U, Berglund J: Determination of novel Borrelia genospecies in Swedish Ixodes ricinus ticks. J Clin Microbiol 2002, 40:3308-3312.

61. Severinsson K, Jaenson TG, Pettersson J, Falk K, Nilsson K: Detection and prevalence of Anaplasma phagocytophilum and Rickettsia helvetica in Ixodes ricinus ticks in seven study areas in Sweden. Parasit Vectors 2010, 3:66.

62. Labuda M, Jones LD, Williams T, Danielova V, Nuttall PA: Efficient transmission of tick-borne encephalitis virus between cofeeding ticks. J Med Entomol 1993, 30:295-299.

63. Labuda M, Kozuch O, Zuffová E, Elecková E, Hails RS, Nuttall PA: Tick-borne encephalitis virus transmission between ticks cofeeding on specific immune natural rodent hosts. Virology 1997, 235:138-143.

64. Gould EA, de Lamballerie X, Zanotto PM, Holmes EC: Origins, evolution, and vector/host coadaptations within the genus Flavivirus. Adv Virus Res 2003, 59:277-314.

65. Nuttall PA, Labuda M: Dynamics of infection in tick vectors and at the tick-host interface. Adv Virus Res 2003, 60:233-272
66. Randolph SE: Population regulation in ticks: the role of acquired resistance in natural and unnatural hosts. Parasitology 1979, 79:141-156.

67. Dizij A, Kurtenbach K: Clethrionomys glareolus, but not Apodemus flavicollis, acquires resistance to Ixodes ricinus L, the main European vector of Borrelia burgdorferi. Parasite Immunol 1995, 17:177-183.

68. Randolph SE, Gern L, Nuttall PA: Co-feeding ticks: epidemiological significance for tick-borne pathogen transmission. Parasitol Today (Regul Ed) 1996, 12:472-479.

69. Achazi K, Rǔžek D, Donoso-Mantke O, Schlegel M, Ali HS, Wenk M, Schmidt-Chanasit J, Ohlmeyer L, Rühe F, Vor T, Kiffner C, Kallies R, Ulrich RG, Niedrig M: Rodents as sentinels for the prevalence of tick-borne encephalitis virus. Vector Borne Zoonotic Dis 2011, 11:641-647.

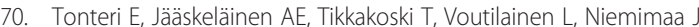
Henttonen $H$, Vaheri A, Vapalahti O: Tick-borne encephalitis virus in wild rodents in winter, Finland, 2008-2009. Emerg Infect Dis 2011, 17:72-75.

71. Bakhvalova VN, Dobrotvorsky AK, Panov W, Matveeva VA, Tkachev SE, Morozova OV: Natural tick-borne encephalitis virus infection among wild small mammals in the southeastern part of western Siberia, Russia. Vector Borne Zoonotic Dis 2006, 6:32-41.

72. Danielová V, Holubová J: Transovarial transmission rates of tick-borne encephalitis virus in Ixodes ricinus ticks. In Modern Acarology. 2nd edition. Edited by Dusbabek F, Bukva V. Prague, Czech Republic: SPB Academic Publishing; 1991:7-10.

73. Alekseev AN: Ecology of tick-borne encephalitis virus: part of Ixodidae ticks males in its circulation. Ecol Parasitol 1992, 1:48-58.

74. Jones LD, Davies CR, Steele GM, Nuttall PA: A novel mode of arbovirus transmission involving a nonviremic host. Science 1987, 237:775-777.

75. Randolph SE, Miklisová D, Lysy J, Rogers DJ, Labuda M: Incidence from coincidence: patterns of tick infestations on rodents facilitate transmission of tick-borne encephalitis virus. Parasitology 1999, 118(Pt 2):177-186

76. Nonaka E, Ebel GD, Wearing HJ: Persistence of pathogens with short infectious periods in seasonal tick populations: the relative importance of three transmission routes. PLOS ONE 2010, 5:e11745.

77. Labuda M, Elečková E, Ličková M, Sabó A: Tick-borne encephalitis virus foci in Slovakia. Int J Med Microbiol 2002, 291:43-47.

78. Skarphédinsson S, Jensen PM, Kristiansen K: Survey of tickborne infections in Denmark. Emerg Infect Dis 2005, 11:1055-1061.

79. Kiffner C, Lödige C, Alings M, Vor T, Rühe F: Attachment site selection of ticks on roe deer, Capreolus capreolus. Exp Appl Acarol 2010, 53:79-94.

80. Zeman $\mathrm{P}$, Januška J: Epizootiologic background of dissimilar distribution of human cases of Lyme borreliosis and tick-borne encephalitis in a joint endemic area. Comp Immunol Microbiol Infect Dis 1999, 22:247-260.

81. Süss J, Schrader C, Falk U, Wohanka N: Tick-borne encephalitis (TBE) in Germany-epidemiological data, development of risk areas and virus prevalence in field-collected ticks and in ticks removed from humans. Int J Med Microbiol 2004, 293(Suppl 37):69-79.

82. Bormane A, Lucenko I, Duks A, Mavtchoutko V, Ranka R, Salmina K, Baumanis $\mathrm{V}$ : Vectors of tick-borne diseases and epidemiological situation in Latvia in 1993-2002. Int J Med Microbio/ 2004, 293(Suppl 37):36-47.

83. Alekseev AN, Chunikhin SP: The experimental transmission of the tick-borne encephalitis virus by ixodid ticks (the mechanisms, time periods, species and sex differences). Parazitologia 1990, 24:177-185.

84. Belova OA, Burenkova LA, Karganova GG: Different tick-borne encephalitis virus (TBEV) prevalences in unfed versus partially engorged ixodid ticks - evidence of virus replication and changes in tick behavior Ticks Tick Borne Dis 2012, 3:240-246.

85. Kuypers J, Wright N, Ferrenberg J, Huang M-L, Cent A, Corey L, Morrow R: Comparison of real-time PCR assays with fluorescent-antibody assays for diagnosis of respiratory virus infections in children. J Clin Microbiol 2006, 44:2382-2388

86. Morozova OV, Dobrotvorsky AK, Livanova NN, Tkachev SE, Bakhvalova VN, Beklemishev AB, Cabello FC: PCR detection of Borrelia burgdorferi sensu lato, tick-borne encephalitis virus, and the human granulocytic ehrlichiosis agent in Ixodes persulcatus ticks from western Siberia, Russia. J Clin Microbiol 2002, 40:3802-3804.

doi:10.1186/1756-3305-7-102

Cite this article as: Pettersson et al:: Prevalence of tick-borne encephalitis virus in Ixodes ricinus ticks in northern Europe with particular reference to Southern Sweden. Parasites \& Vectors 2014 7:102 